\title{
Bridged-Selective Intramolecular Diels-Alder Reactions in the Synthesis of Bicyclo[2.2.2]octanes
}

\author{
Mika Hanashima, Toshiki Matsumura, Yuta Asaji, Tomoyuki Yoshimura, and Jun-ichi Matsuo* \\ Division of Pharmaceutical Sciences, Graduate School of Medical Sciences, Kanazawa University; Kakuma-machi, \\ Kanazawa, Ishikawa 920-1192, Japan. \\ Received July 20, 2020; accepted September 10, 2020
}

\begin{abstract}
Regioselectivity for intramolecular Diels-Alder (IMDA) reactions of 6-acetoxy-6-alkenylcyclohexa-2,4dien-1-ones that were formed by oxidation of 2 -alkenylphenols with lead tetraacetate in acetic acid were studied. Bridged regioselectivity was observed in the IMDA reactions of 6-acetoxy-6-alkenylcyclohexa-2,4dien-1-ones having a dienophile part which could conjugate with an aromatic group. Bridged seven- and eight-membered rings and bicyclo[2.2.2] octane skeletons were constructed by the present IMDA reactions. Density functional theory (DFT) calculations suggested that conjugation of the dienophile with neighboring aromatic groups lowered the highest occupied molecular orbital-lowest unoccupied molecular orbital (HOMO-LUMO) energy gap and preceded bridged $[4+2]$ adducts.
\end{abstract}

Key words intramolecular Diels-Alder reaction; bridged regioselectivity; medium ring; bicyclo[2.2.2]octane; density functional theory (DFT) calculation

\section{Introduction}

Intramolecular Diels-Alder (IMDA) reactions ${ }^{1-6)}$ are important reactions for organic synthesis of complex molecules having a six-membered ring with multiple stereogenic centers because of their predictable regiochemistry and stereochemistry. There are two modes in IMDA reactions, which give fused or bridged compounds (Chart 1).

Fused compounds are generally formed by IMDA reactions because of their straight arrangement between diene and dienophile parts. $^{7-10)}$ On the other hand, bridged compounds were obtained selectively in a few cases. Greuter reported that the IMDA reaction of $(Z)-\mathbf{1}$ that was formed by isomerization (E)-1 gave a bridged seven-membered compound $\mathbf{2}$ in $35 \%$ yield as a main product along with a fused isomer $\mathbf{3}$ in $5 \%$ yield $^{11-13)}$ (Chart 2).

As another bridged-selective IMDA reaction, Cook and Danishefsky reported that oxidative dearomatization of a phenol $^{14,15)}$ in the presence of an allenyl alcohol gave a bridged compound 4 instead of a fused one $5^{16)}$ (Chart 3 ). De Lera and colleagues proposed that stabilization of diradical species in the IMDA reaction was a key factor for the bridged selectivity. ${ }^{17)}$

Although effects of a Lewis acid ${ }^{18)}$ and effects of electronic factors $^{19)}$ for bridged selectivity have been reported, there has been limited information for favoring bridged products in IMDA reactions. ${ }^{20)}$ Here, we report the effects of the structure of the tether part between an alkene and a diene in 7, which were formed by oxidation of a 2 -alkenyl phenol $\mathbf{6}$, in an IMDA reaction to a fused product 8 or a bridged one 9 (Chart 4).

\section{Results and Discussion}

Yates and Auksi reported that Wessely oxidation ${ }^{21-23)}$ of $\mathbf{6 a}$ and $\mathbf{6 b}$ with $\mathrm{Pb}(\mathrm{OAc})_{4}$ in acetic acid followed by IMDA reactions of $\mathbf{7 a}$ and $\mathbf{7 b}$ gave fused adducts $\mathbf{8} \mathbf{a}^{24)}$ and $\mathbf{8} \mathbf{b}^{18)}$ in low yields (Table 1, entries 1 and 2). We investigated the effects of the length of a tether by using 2-alkenylphenol 6c. Wessely oxidation of $\mathbf{6 c}$ was found to give the corresponding $7 \mathbf{c}$ in $28 \%$ yield (entry 3 ). However, an IMDA reaction of $7 \mathbf{c}$ gave complex mixtures probably due to flexibility of the tether part.

Next, IMDA reactions of phenols $\mathbf{6 d}$, e, which had a 2-vinylphenyl group, were studied. Wessely oxidation of a phenol 6d at room temperature directly gave a fused Diels-Alder product $\mathbf{8 d}$ in $23 \%$ yield (entry 4 ). The corresponding dienone 7d and a bridged [4+2] adduct 9d were not obtained. The structure of $\mathbf{8 d}$ was determined unambiguously by its X-ray crystallography. ${ }^{25)}$ A one-carbon-homologated phenol 6 was oxidized to $7 \mathbf{e}$ and the IMDA reaction of $7 \mathbf{e}$ in refluxing xylenes gave a bridged product 9e in $73 \%$ yield without formation of a fused product $8 \mathbf{e}$ (entry 5). The structure of 9e was determined by heteronuclear multiple bond connectivity (HMBC) correlations. ${ }^{25}$ ) Therefore, it was found that one-carbon homologation (7d to $7 \mathbf{7}$ ) dramatically changed the fused or bridged selectivity in the IMDA reactions.

In order to study further effects of an extended tether, phenols $6 \mathbf{f}$ and $\mathbf{6 g}$ having a maleimide group and a 2-nitroethynyl group as a strong dienophile part were designed since difficulty of IMDA reactions of dienones 7 having a longer tether was expected (For structures of $\mathbf{6} \mathbf{f}$ and $\mathbf{6 g}$, see Charts 5 and 6). Methoxy groups of $\mathbf{6 g}$ were introduced for synthesis of a colchicine ${ }^{26)}$-like structure, $8 \mathrm{~g}$ or $\mathbf{9 g}$.

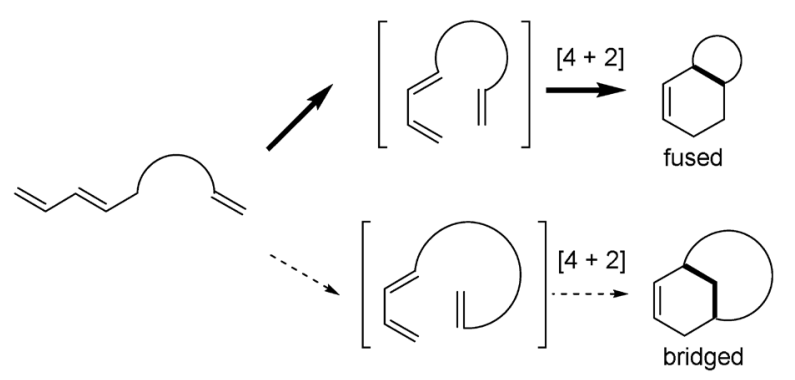

Chart 1. Intramoleculan Diels-Alder (IMDA) Reactions Affording Fused and Bridged Products 
A phenol of having a maleimide group was prepared as shown in Chart 5. Wittig reaction of aldehyde $\mathbf{1 0}$ with $\mathbf{1 1}$ gave a stilbene derivative $\mathbf{1 2}$ in $85 \%$ yield. Catalytic hydrogenation of 12 by $\mathrm{H}_{2}$ and $\mathrm{Pd} / \mathrm{C}$ or $\mathrm{PtO}_{2}$ did not give a desired product 13, but hydrogenation with $\mathrm{TsNHNH}_{2} / \mathrm{NaOAc}$ afforded $\mathbf{1 3}$ in $90 \%$ yield. ${ }^{27)}$ Heck reaction of aryl iodide $\mathbf{1 3}$ with maleimide gave a Heck product $\mathbf{1 4}$ in $29 \%$ yield by using $20 \mathrm{~mol} \%$ of $\mathrm{Pd}(\mathrm{OAc})_{2}$ and $20 \mathrm{~mol} \%$ of DPEphos ((oxydi-2,1-phenylene)-

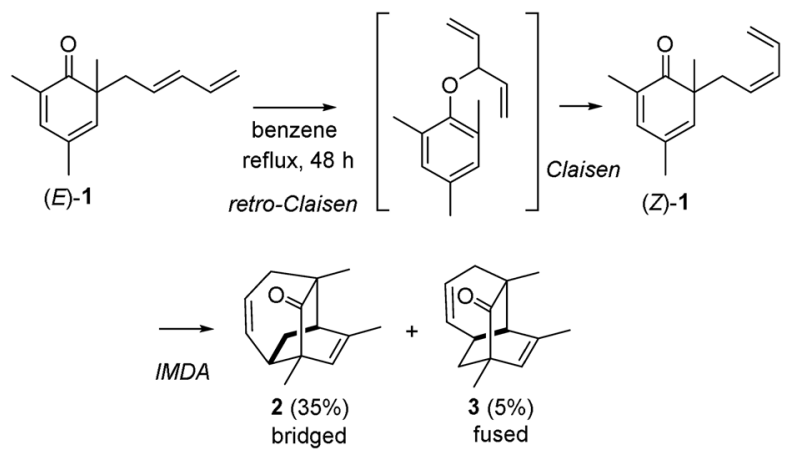

Chart 2. A Bridged-Selective IMDA Reaction of (Z)-1
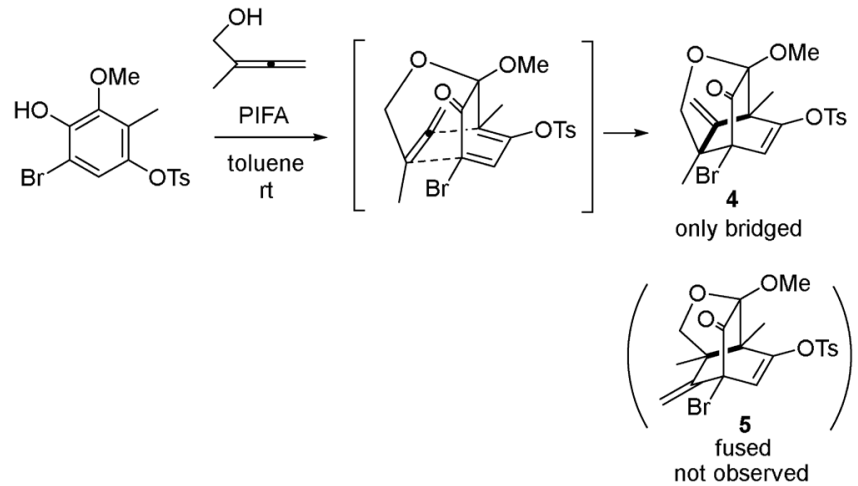

Chart 3. A Bridged-Selective IMDA Reaction Reported by Danishefsky et al. bis(diphenylphosphine)) in the presence of KOAc in ethylene carbonate. ${ }^{28)}$ The use of dppe (ethylenebis(diphenylphosphine)) instead of DPEphos did not provide 14. The low yield of 14 might result from a labile maleimide unit under the Heck reaction conditions. Removal of the tert-butyldimethylsilyl (TBS) group of 14 with HF-pyridine gave the phenol 15 in 95\% yield.

Preparation of $\mathbf{6 g}$ is shown in Chart 6. Wittig reaction of aldehyde $\mathbf{1 0}$ with $\mathbf{1 5}$ afforded a stilbene derivative $\mathbf{1 6}$ in $95 \%$

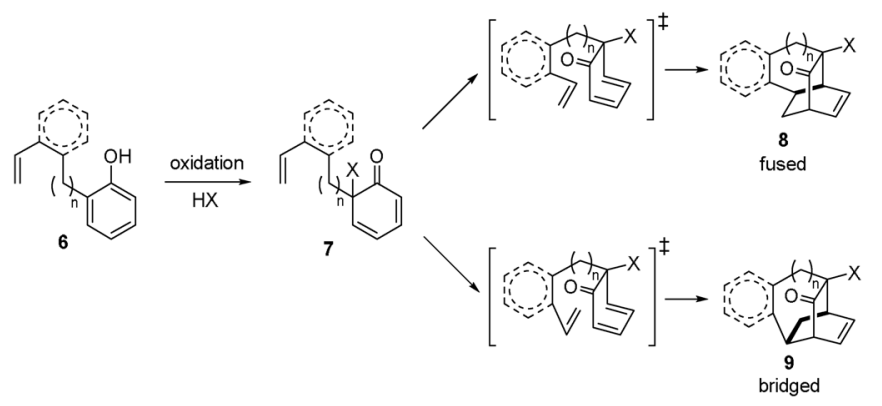

Chart 4. Effects of the Tether Part for an IMDA Reaction of 7 to a Fused Product $\mathbf{8}$ or a Bridged One 9

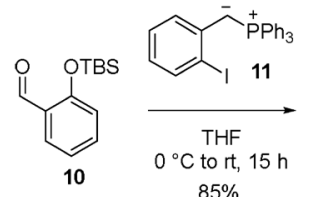

$85 \%$<smiles></smiles>

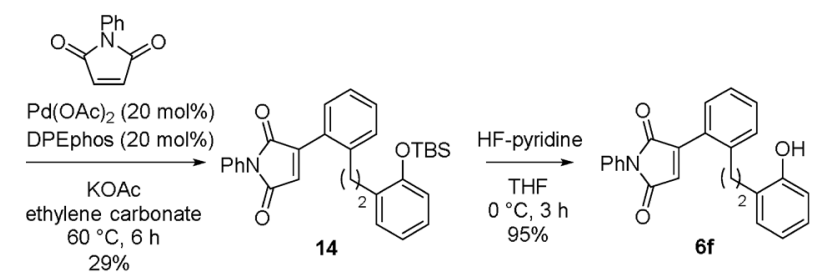

$6 f$

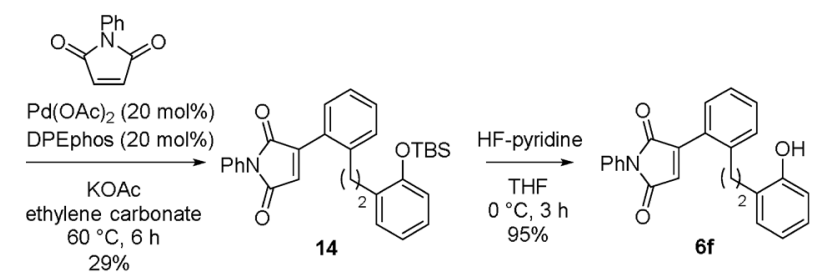

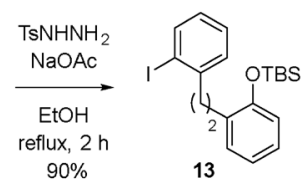

13
Chart 5. Preparation of $\mathbf{6} \mathbf{f}$

Table 1. Wessely Oxidation of $\mathbf{6}$ and IMDA Reactions of 7

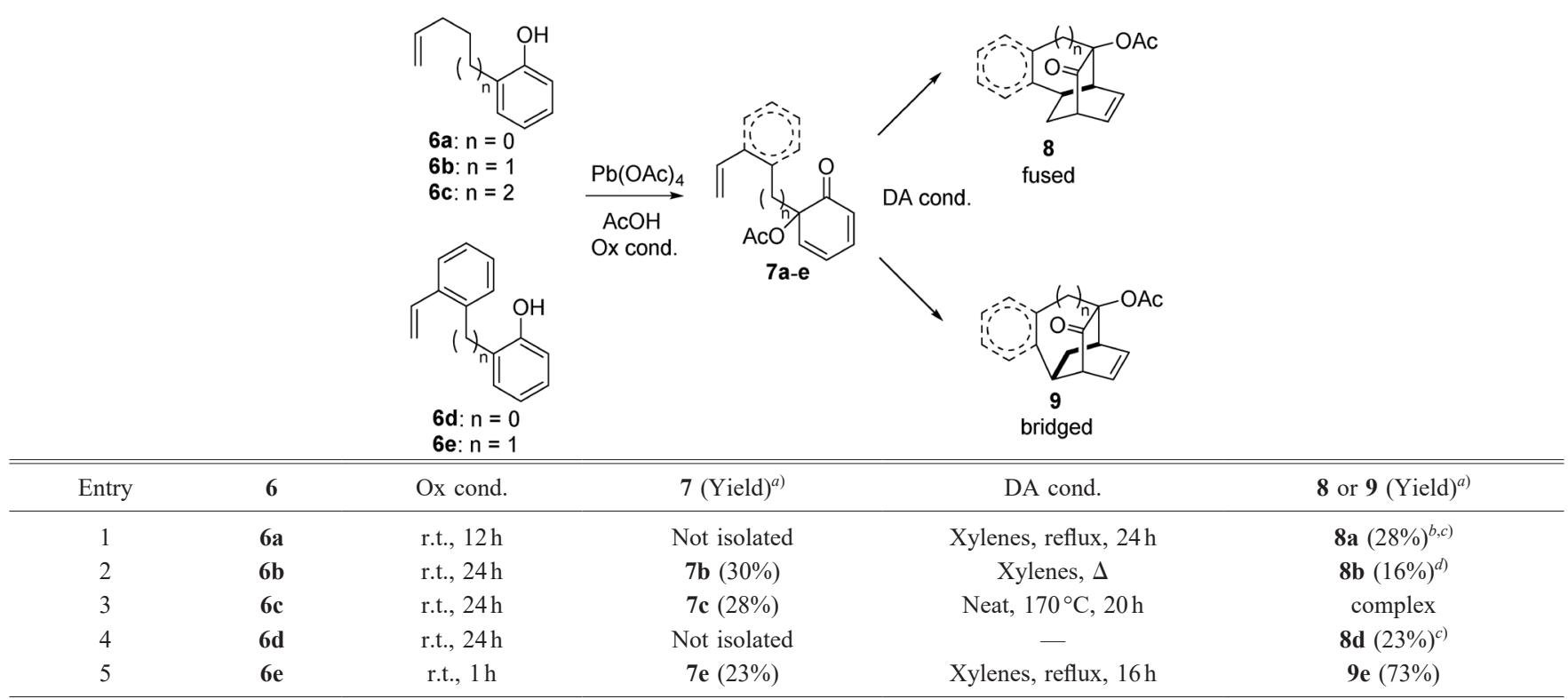

a) Isolated yield. $b$ ) Ref. 24. c) Yield for two steps. $d$ ) Ref. 18. 
yield. Reduction of $\mathbf{1 6}$ using $\mathrm{TsNHNH}_{2}$ and $\mathrm{NaOAc}$ gave a 1,2-diphenylethane $\mathbf{1 7}$ in $91 \%$ yield. ${ }^{27}$ ) Halogen-lithium exchange followed by a reaction with $N, N$-dimethylformamide (DMF) gave an aldehyde 18. Nitro aldol reaction of $\mathbf{1 8}$ with nitromethane provided a nitroalkene 19 in $40 \%$ in two steps. Removal of the TBS group of $\mathbf{1 9}$ with tetrabutylammonium fluoride (TBAF) gave $\mathbf{6 g}$ quantitatively.

With phenols 6f,g having strong dienophiles in hand, fused/ bridged regioselectivity in their IMDA reactions were investigated. Oxidation of $\mathbf{6 f}$ with $\mathrm{Pb}(\mathrm{OAc})_{4}$ in $\mathrm{AcOH}$ afforded an acetoxy-2,4-cyclohexadien-1-one $7 \mathbf{f}$ in 34\% yield (Chart 7). The IMDA reaction of $7 \mathbf{f}$ at $170{ }^{\circ} \mathrm{C}$ for $3.5 \mathrm{~h}$ without using a solvent gave a bridged $[4+2]$ adduct $9 f$ in $52 \%$ yield, and a fused adduct $\mathbf{8 f}$ was not detected. The structure of $\mathbf{9 f}$ was determined by HMBC correlations and nuclear Overhauser effect (NOE). ${ }^{25)}$

Wessely oxidation of $\mathbf{6 g}$ with $\mathrm{Pb}(\mathrm{OAc})_{4}$ gave dienone $\mathbf{7 g}$ in $43 \%$ yield (Table 2 ). However, the IMDA reaction of $7 \mathbf{g}$ did
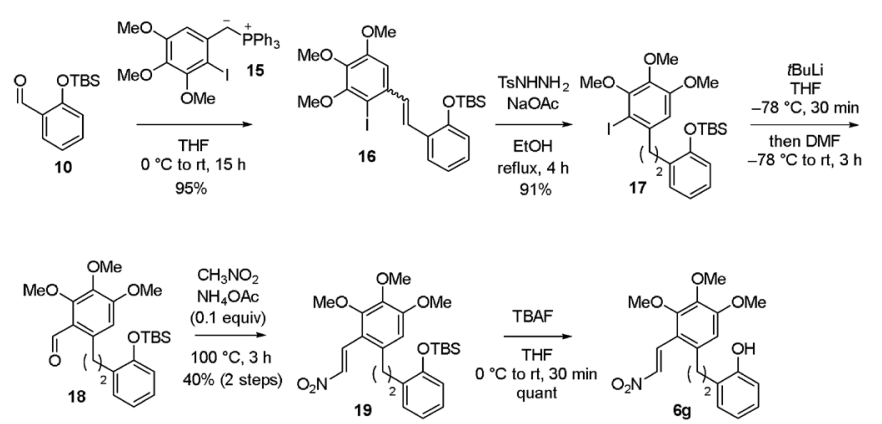

Chart 6. Preparation of $\mathbf{6 g}$ not proceed at $165^{\circ} \mathrm{C}$ (entry 1). Attempted activation of the nitro group with a thiourea catalyst $\mathbf{2 0}^{29,30}$ was not effective (entry 2). Danishefsky and colleagues reported that the use of 2,2,2-trifluoroethanol as a solvent improved the efficiency of Diels-Alder reactions of nitroalkenes. ${ }^{31)}$ Investigation of the effects of some fluoroalkyl alcohols as solvents revealed that 2,2,2-trifluoroethanol was the most effective for the IMDA reaction of $\mathbf{7 g}$ (entry 3 ). In this case, a bridged IMDA product 9g was formed selectively, and $19 \%$ of the starting material $7 \mathrm{~g}$ was recovered with many unidentified byproducts. It was assumed that 2,2,2-trifluoroethanol activated the nitro group of $7 \mathrm{~g}$ by its hydrogen bond.

Experimental results showed that the IMDA reaction of compound 7d that had no methylene unit between a 2-vinylphenyl group and a dienone group gave the fused compound 8d selectively, while the IMDA reaction of compounds $\mathbf{7 e -} \mathbf{g}$ that had the one or two methylene units afforded bridged compounds $9 \mathbf{e}-\mathbf{g}$. In order to clarify the reason for the change of selectivity, density functional theory (DFT) calculations $(\mathrm{B} 3 \mathrm{LYP} / 6-31(\mathrm{~d}, \mathrm{p}) \text { or } \mathrm{B} 3 \mathrm{LYP} / 6-31 \mathrm{G}(\mathrm{d}))^{32,33)}$ of IMDA reactions of $\mathbf{7 d}, \mathbf{e}, \mathbf{b}, \mathbf{f}$ were performed (Fig. 1). DFT calculation $(B 3 L Y P / 6-31(d, p))$ of the IMDA reaction of $7 \mathbf{d}$ to the fused compound $\mathbf{8 d}$ or the bridged compound $9 \mathbf{d}$ is shown in Fig. 1(a). TS 21, which gives fused $\mathbf{8 d}$, is $6.7 \mathrm{kcal} / \mathrm{mol}$ lower than TS 22, which gives bridged 9d. The fused compound $\mathbf{8 d}$ is thermodynamically stable in $7.2 \mathrm{kcal} / \mathrm{mol}$ compared with the bridged compound $9 \mathbf{d}$. Therefore, the reaction path from $\mathbf{7 d}$ to fused $\mathbf{8 d}$ is preferred both in kinetic and thermodynamic aspects. In fact, the fused compound $\mathbf{8 d}$ was selectively formed from 7d (Table 1, entry 4).

DFT calculation (B3LYP/6-31(d)) of the IMDA reactions

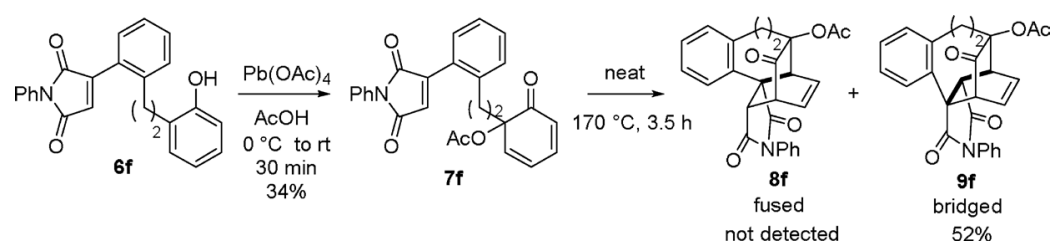

Chart 7. Wessely Oxidation of $\mathbf{6 f}$ and the IMDA Reaction of $7 \mathbf{f}$

Table 2. The IMDA Reaction of $\mathbf{7 g}$

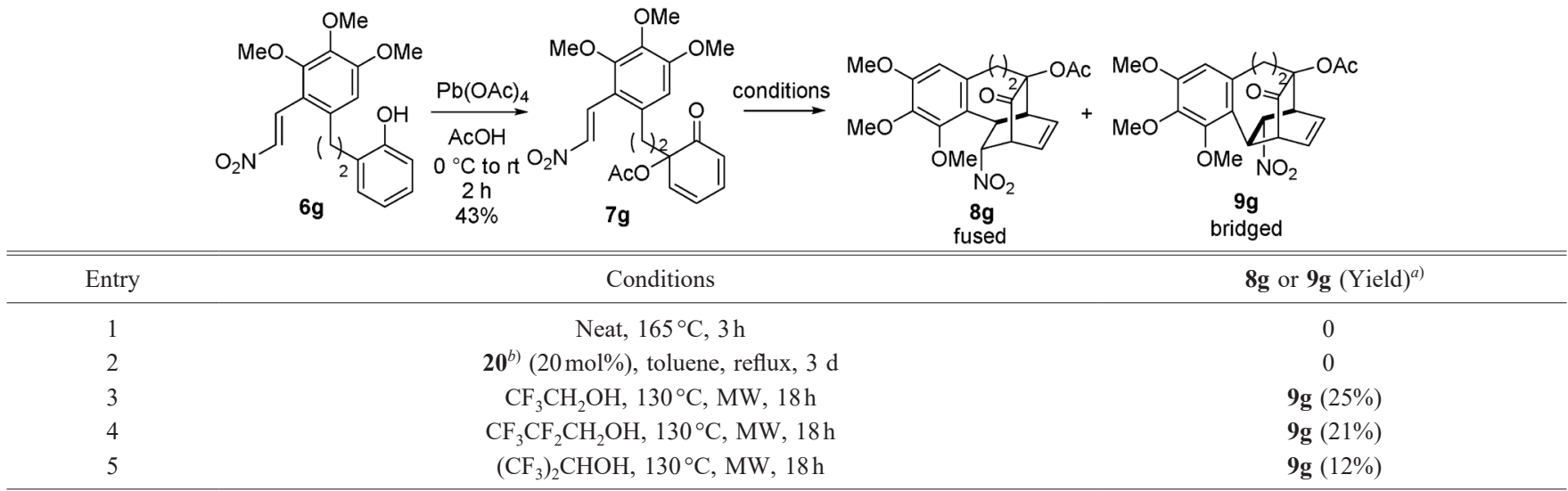

a) Isolated yield. b) 


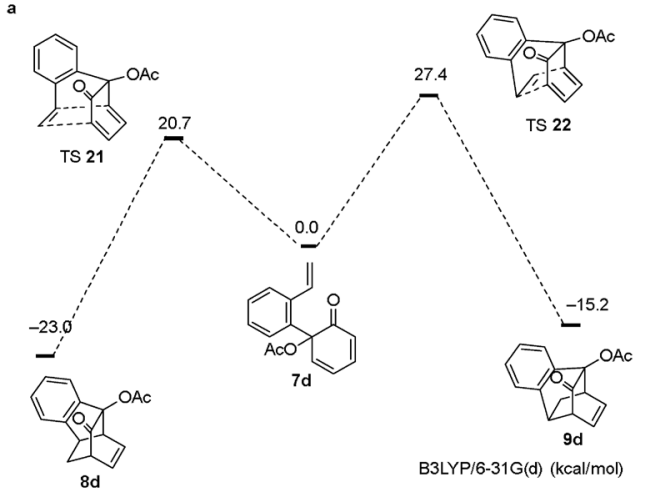

c

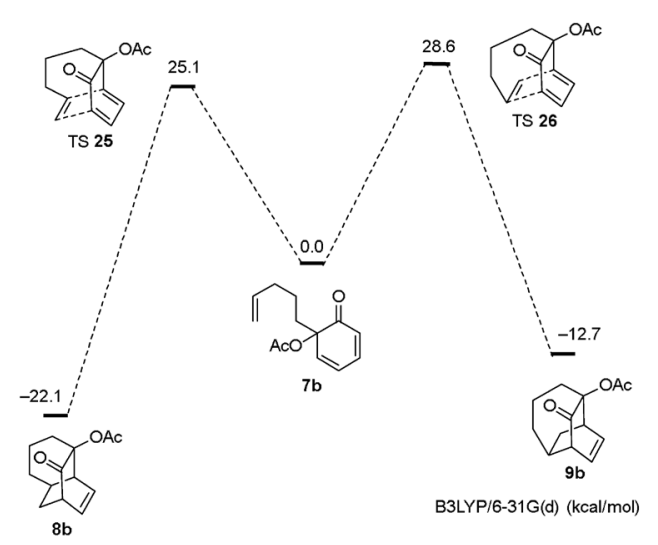

Fig. 1. DFT Calculations of IMDA Reactions of $\mathbf{7 d}, \mathbf{e}, \mathbf{b}, \mathbf{f}$

of $\mathbf{7 e}$ indicated that TS $\mathbf{2 3}$, which gives the fused compound $\mathbf{8 e}$, is less stable $(2.2 \mathrm{kcal} / \mathrm{mol})$ than TS $\mathbf{2 4}$, which gives the bridged product 9e (Fig. 1(b)). It was also pointed out that fused $8 \mathbf{e}$ is more stable $(5.5 \mathrm{kcal} / \mathrm{mol})$ than bridged $9 \mathbf{e}$. The experimental result of selective formation of the bridged product 9e from 7e (Table 1, entry 5) suggests that the reaction path is kinetically controlled, reflecting the lower energy of TS $\mathbf{2 4}$.

Judging from the result of DFT calculation (B3LYP/6-31(d)) of the IMDA reaction of $\mathbf{7 b}$ (Fig. 1(c)), it is expected that a fused product $\mathbf{8 b}$ would be preferably formed rather than a bridged product $\mathbf{9 b}$ since TS $\mathbf{2 5}$, which gives $\mathbf{8 b}$, is favored by $3.5 \mathrm{kcal} / \mathrm{mol}$ than TS 26. This calculation is supported by the experimental result that the IMDA reaction of $\mathbf{7 b}$ gave $\mathbf{8 b}$ in $16 \%$ yield and $9 \mathrm{~b}$ was not isolated (Table 1 , entry 2 ). ${ }^{18)}$ Therefore, experimental results and the calculations of IMDA reactions of $7 \mathbf{b}$ and $7 \mathbf{e}$ suggest that the presence of the phenyl ring in the tether structure of $7 \mathbf{e}$ is important for favoring bridged selectivity through TS 24.

As in the case of 7e, DFT calculation (B3LYP/6-31(d)) of the IMDA reaction of $\mathbf{7 f}$ (Fig. 1(d)) pointed out that TS $\mathbf{2 8}$, which gives the bridged product 9f, is lower in $3.7 \mathrm{kcal} / \mathrm{mol}$ than TS 27, which gives a fused compound 8f. The experimental result showing selective formation of 9 f (Chart 7) reflects the lower energy of TS 28. In TS 28, the phenyl group and the maleimide group have a highly co-planar conformation (see Supplementary Material, Figure SI2), while these two groups are twisted in TS 27 (see Supplementary Material, Figure SI1). Conjugation between the phenyl and maleimide groups lowers the lowest unoccupied molecular orbital (LUMO) energy of TS 28, and this results in lowering the highest occupied b

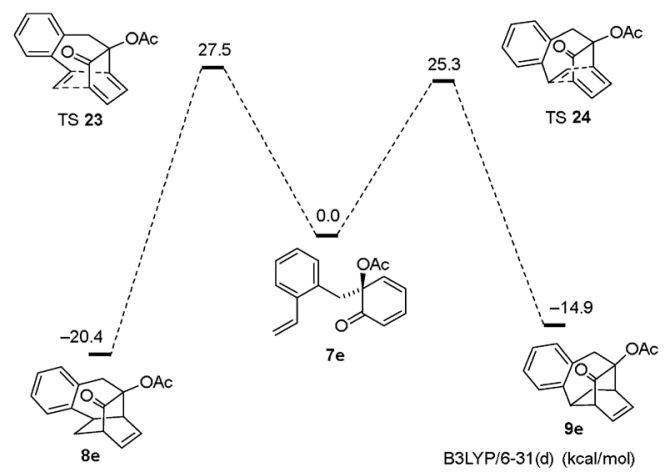

d

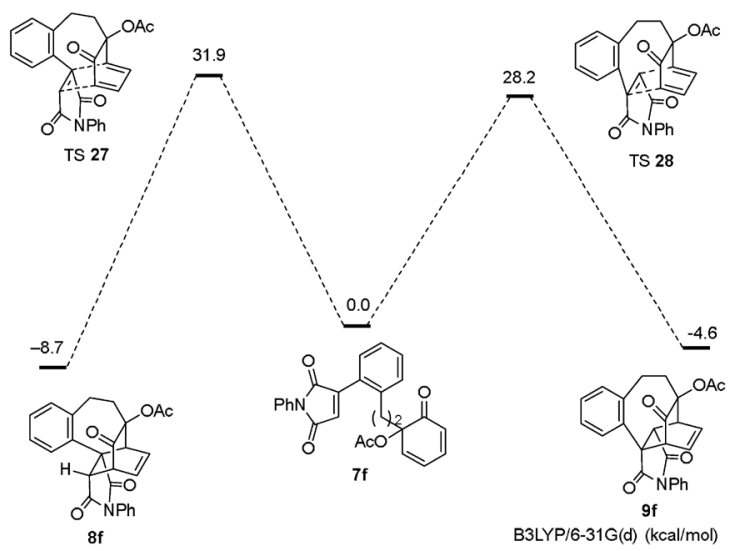

molecular orbital (HOMO)-LUMO energy gap for IMDA reactions. Similar conjugation between the phenyl group and the dienophile is considered in TS $\mathbf{2 4}$ from compound 7e. However, in the case of 7d, conjugation of the vinyl group with the phenyl group was difficult both in TS 21 and TS 22 because of their restricted transition states.

\section{Conclusion}

In conclusion, we found that the presence of a phenyl ring which could conjugate a dienophile part favored bridgedselective IMDA reactions of alkenyl dienones formed by oxidation of 2-alkenylphenols except in the case of a short tether. DFT calculations suggested that a transition state that gave a bridged product had a co-planar conformation between a phenyl ring and a dienophile part, and conjugation of the two co-planar groups lowered the HOMO-LUMO energy gap for IMDA reactions. Bridged-selective construction of an eightmembered ring in $\mathbf{9 f}, \mathbf{g}$ was performed by IMDA reactions. These results will help in the planning of bridged-selective IMDA reactions for synthesis of complex molecules.

\section{Experimental}

General All melting points were determined on Yanagimoto micro melting point apparatus and are uncorrected. IR spectra were recorded on Horiba IR-710. ${ }^{1} \mathrm{H}-\mathrm{NMR}$ spectra were recorded on a JEOL JNM ECA600 $(600 \mathrm{MHz})$ or a JEOL JNM ECS400 $(400 \mathrm{MHz})$ spectrometer at room temperature (r.t.); chemical shifts $(\delta)$ are reported in parts per million relative to tetramethylsilane. Splitting patterns are designated as s, singlet; d, doublet; $t$, triplet; q, quartet; sept, septet; m, mul- 
tiplet; br, broad. ${ }^{13} \mathrm{C}-\mathrm{NMR}$ spectra were recorded on a JEOL JNM ECA600 $(150 \mathrm{MHz})$ or a JEOL JNM ECS400 (100 MHz) spectrometer with complete proton decoupling. chemical shifts are reported in parts per million relative to tetramethylsilane with the solvent resonance as the internal standard $\mathrm{CDCl}_{3}$. High resolution (HR)MS were recorded on a JEOL JMS-T100TD. X-ray crystallographic analysis was performed on Rigaku R-AXIS RAPIDII-S. Analytical TLC was performed on Merck precoated TLC plates (silica gel 60 GF254, $0.25 \mathrm{~mm}$ ). Silica gel column chromatography was carried out on silica gel 60N (Kanto Kagaku Co., Ltd., spherical neutral, 63-210 or $40-50 \mu \mathrm{m})$. Preparative thin-layer chromatography (PTLC) was carried out on silica gel Wakogel B-5F. All reactions were carried out under nitrogen in dried glassware with magnetic stirring. Microwave experiments were carried out in sealed vessels in a synthesis reactor (Biotage Initiator 2.5). Compounds $\mathbf{6 b}, \mathbf{c}$ were prepared by the reported method. ${ }^{34)}$

Synthesis of 2-(2-Vinylphenyl)phenol (6d) $)^{35)}$ To a cooled suspension of methyltriphenylphosphonium iodide $(128 \mathrm{mg}$, $0.318 \mathrm{mmol}$ ) in tetrahydrofuran (THF) $(3 \mathrm{~mL})$ at $0{ }^{\circ} \mathrm{C}$ was added potassium tert-butoxide $(56 \mathrm{mg}, 0.50 \mathrm{mmol})$ under nitrogen. After $30 \mathrm{~min}$, 6H-benzo[c]chromen-6-one ${ }^{36)}(25 \mathrm{mg}$, $0.15 \mathrm{mmol}$ ) which was prepared from phenyl 2-bromobenzoate was added. The reaction was warmed to r.t. and the mixture was stirred for $15 \mathrm{~h}$. After dropping $1 \mathrm{~N} \mathrm{HCl}$ until $\mathrm{pH}$ below 7, the aqueous phase was separated and extracted with DCM. The combined organic extracts were washed with brine, dried over anhydrous $\mathrm{Na}_{2} \mathrm{SO}_{4}$, and concentrated in vacuo. The crude product was purified by column chromatography on silica gel (Hexane/EtOAc) to give the product $\mathbf{6 d}(20 \mathrm{mg}, 0.12 \mathrm{mmol}$, $81 \%)$. Compound 6d: ${ }^{1} \mathrm{H}-\mathrm{NMR}\left(\mathrm{CDCl}_{3}, 400 \mathrm{MHz}\right) \delta: 7.72(1 \mathrm{H}$, $\mathrm{d}, J=7.2 \mathrm{~Hz}), 7.49-7.20(4 \mathrm{H}, \mathrm{m}), 7.13(1 \mathrm{H}, \mathrm{d}, J=6.8 \mathrm{~Hz}), 6.99$ $(2 \mathrm{H}, \mathrm{d}, J=6.8 \mathrm{~Hz}), 6.56(1 \mathrm{H}, \mathrm{dd}, J=17.6,11.2 \mathrm{~Hz}), 5.75(1 \mathrm{H}, \mathrm{d}$, $J=17.6 \mathrm{~Hz}), 5.22(1 \mathrm{H}, \mathrm{d}, J=11.2 \mathrm{~Hz}), 4.80(1 \mathrm{H}, \mathrm{s}) ;{ }^{13} \mathrm{C}-\mathrm{NMR}$ $\left(\mathrm{CDCl}_{3}, 100 \mathrm{MHz}\right) \delta: 152.6,136.7,134.9,134.4,130.9,130.7$, 129.4, 128.6, 128.4, 126.7, 125.6, 120.5, 115.9, 115.5 .

Synthesis of 2-(2-Vinylbenzyl)-1-(tert-butyldimethylsilyloxy)benzene (6e) A mixture of 1-bromomethyl-2-tertbutyldimethylsilyloxybenzene $(1.38 \mathrm{~g}, 4.59 \mathrm{mmol})$, 2-formylphenylboronic acid $(688 \mathrm{mg}, 4.59 \mathrm{mmol}), \mathrm{Pd}\left(\mathrm{PPh}_{3}\right)_{4}(133 \mathrm{mg}$, $0.115 \mathrm{mmol}), \mathrm{K}_{2} \mathrm{CO}_{3}(1.90 \mathrm{~g}, 13.8 \mathrm{mmol})$ in THF $(15 \mathrm{~mL})$ was heated at $95^{\circ} \mathrm{C}$ for $12 \mathrm{~h}$. After cooling to room temperature, he reaction mixture was diluted by adding $\mathrm{H}_{2} \mathrm{O}$ and ethyl acetate. The mixture was extracted with ethyl acetate (three times), and the combined organic extracts were dried over anhydrous $\mathrm{Na}_{2} \mathrm{SO}_{4}$, filtered, and concentrated. The crude product was purified by column chromatography on silica gel (hexanes/ethyl acetate $=10: 1)$ to afford 2-(2-((tert-butyldimethylsilyl)oxy)benzyl)benzaldehyde (29) (1.20 g, $3.68 \mathrm{mmol}, 80 \%)$. Compound 29: ${ }^{1} \mathrm{H}-\mathrm{NMR}\left(\mathrm{CDCl}_{3}, 600 \mathrm{MHz}\right) \delta$ : $10.26(1 \mathrm{H}, \mathrm{s}), 7.88(1 \mathrm{H}, \mathrm{d}$, $J=7.6 \mathrm{~Hz}), 7.49(1 \mathrm{H}, \mathrm{t}, J=6.8 \mathrm{~Hz}), 7.39(1 \mathrm{H}, \mathrm{t}, J=7.2 \mathrm{~Hz})$, 7.15-7.10 (2H, m), 6.85-6.83 (3H, m), $4.00(2 \mathrm{H}, \mathrm{s}), 0.92(9 \mathrm{H}$, s), $0.23(6 \mathrm{H}, \mathrm{s}) ;{ }^{13} \mathrm{C}-\mathrm{NMR}\left(\mathrm{CDCl}_{3}, 150 \mathrm{MHz}\right) \delta$ : 192.4, 153.3, $143.2,134.0,133.8,131.1,131.0,130.7,130.5,127.4,126.7$, 121.2, 118.3, 32.6, 25.7, 18.2, -4.2; IR $\left(\mathrm{CHCl}_{3}, \mathrm{~cm}^{-1}\right): 2958$, 2931, 2860, 1693; HRMS (DART+): $\mathrm{m} / \mathrm{z}[\mathrm{M}+\mathrm{H}]^{+}$Calcd for $\mathrm{C}_{20} \mathrm{H}_{26} \mathrm{O}_{2} \mathrm{Si}: 327.17803$. Found: 327.17867 .

To a stirred mixture of methyltriphenylphosphonium iodide (1.95 g, $4.82 \mathrm{mmol}), t$-BuOK ( $800 \mathrm{mg}, 7.13 \mathrm{mmol})$ in THF $(50 \mathrm{~mL})$ was added a solution of $29(750 \mathrm{mg}, 2.30 \mathrm{mmol})$ in THF $(30 \mathrm{~mL})$ at $0{ }^{\circ} \mathrm{C}$ for $4 \mathrm{~h}$. The reaction was quenched by addition of a solution of hydrochloric acid $(<\mathrm{pH} 7.0)$, and the mixture was extracted with ethyl acetate. The combined organic extracts were dried over anhydrous $\mathrm{Na}_{2} \mathrm{SO}_{4}$, filtered, and concentrated. The crude product was purified by column chromatography on silica gel (hexanes) to afford the corresponding Wittig product (528 mg, $1.63 \mathrm{mmol}, 71 \%$ ).

To a stirred solution of the Wittig product $(500 \mathrm{mg}$, $1.54 \mathrm{mmol})$ in THF $(10 \mathrm{~mL})$ was added a solution of TBAF in THF $(1.0 \mathrm{M}, 2.3 \mathrm{~mL}, 2.3 \mathrm{mmol})$ at $0{ }^{\circ} \mathrm{C}$, and the reaction mixture was stirred at $0{ }^{\circ} \mathrm{C}$ for $25 \mathrm{~min}$. The reaction was quenched by adding a solution of saturated aqueous $\mathrm{NH}_{4} \mathrm{Cl}$. The resulting mixture was extracted with ethyl acetate (three times), and the combined organic extracts were washed with brine, dried over anhydrous $\mathrm{Na}_{2} \mathrm{SO}_{4}$, filtered, and concentrated. The crude product was purified by column chromatography on silica gel (hexanes/ethyl acetate $=10: 1)$ to afford $\mathbf{6 e}(364 \mathrm{mg}, 1.17 \mathrm{mmol}$, $76 \%)$. Compound 6e: ${ }^{1} \mathrm{H}-\mathrm{NMR}\left(\mathrm{CDCl}_{3}, 600 \mathrm{MHz}\right) \delta: 7.42(1 \mathrm{H}$, $\mathrm{d}, J=7.2 \mathrm{~Hz}), 7.15-7.07(2 \mathrm{H}, \mathrm{m}), 7.01-6.95(2 \mathrm{H}, \mathrm{m}), 6.86(1 \mathrm{H}$, dd, $J=17.4,11.4 \mathrm{~Hz}), 6.78(1 \mathrm{H}, \mathrm{d}, J=7.2 \mathrm{~Hz}), 6.73(1 \mathrm{H}, \mathrm{t}$, $J=7.8 \mathrm{~Hz}), 6.65(1 \mathrm{H}, \mathrm{d}, J=8.4 \mathrm{~Hz}), 5.53(1 \mathrm{H}, \mathrm{d}, J=17.4 \mathrm{~Hz})$, $5.15(1 \mathrm{H}, \mathrm{d}, J=11.4 \mathrm{~Hz}), 4.73(1 \mathrm{H}, \mathrm{s}), 3.92(2 \mathrm{H}, \mathrm{s}) ;{ }^{13} \mathrm{C}-\mathrm{NMR}$ $\left(\mathrm{CDCl}_{3}, 150 \mathrm{MHz}\right) \delta: 153.4,137.1,136.6,134.5,130.5,129.8$, $128.0,127.6,126.8,126.5,126.0,120.9,116.0,115.3,33.0$; IR $\left(\mathrm{CHCl}_{3}, \mathrm{~cm}^{-1}\right): 3597,3010$; HRMS (DART+): $\mathrm{m} / z[\mathrm{M}+\mathrm{H}]^{+}$ Calcd for $\mathrm{C}_{14} \mathrm{H}_{13} \mathrm{O}_{1}$ : 197.09664. Found: 197.09670.

The IMDA Reaction of 6d to 8d (Table 1, Entry 4) To a solution of $\mathbf{6 d}(68 \mathrm{mg}, 0.35 \mathrm{mmol})$ in $\mathrm{AcOH}(3 \mathrm{~mL})$ was added $\mathrm{Pb}(\mathrm{OAc})_{4}(922 \mathrm{mg}, 2.08 \mathrm{mmol})$ at $0^{\circ} \mathrm{C}$, and the reaction temperature was allowed to reach room temperature. After $72 \mathrm{~h}$, the precipitate was filtered off with EtOAc, and the filtrate was washed with saturated aqueous solution of $\mathrm{NaHCO}_{3}$. The organic phase was dried over anhydrous $\mathrm{Na}_{2} \mathrm{SO}_{4}$, filtered, and concentrated in vacuo. The crude product was purified by column chromatography on silica gel (EtOAc/Hexane) to yield 8d $(21 \mathrm{mg}, 0.08 \mathrm{mmol}, 23 \%)$ as a yellow solid. Compound 8d: mp: $128.0-129.0^{\circ} \mathrm{C}$ (recryst. from $\left.\mathrm{CH}_{2} \mathrm{Cl}_{2}\right)$; ${ }^{1} \mathrm{H}-\mathrm{NMR}\left(\mathrm{CDCl}_{3}\right.$, $600 \mathrm{MHz}) \delta: 7.26-7.18(4 \mathrm{H}, \mathrm{m}), 6.59(1 \mathrm{H}, \mathrm{t}, J=6.0 \mathrm{~Hz}), 6.39$ $(1 \mathrm{H}, \mathrm{t}, J=6.6 \mathrm{~Hz}), 4.38-4.35(1 \mathrm{H}, \mathrm{m}), 3.42-4.39(1 \mathrm{H}, \mathrm{m})$, 3.27-3.22 (1H, m), $2.16(3 \mathrm{H}, \mathrm{s}), 1.89-1.88(2 \mathrm{H}, \mathrm{m}) ;{ }^{13} \mathrm{C}-\mathrm{NMR}$ $\left(\mathrm{CDCl}_{3}, 150 \mathrm{MHz}\right) \delta: 202.3,169.2,146.2,139.3,132.3,131.5$, 129.0, 127.2, 123.6, 122.6, 85.5, 52.1, 51.0, 38.4, 37.6, 21.5; IR $\left(\mathrm{CHCl}_{3}, \mathrm{~cm}^{-1}\right): 2951,1738 ; \operatorname{HRMS}(\mathrm{DART}+): \mathrm{m} / \mathrm{z}[\mathrm{M}+\mathrm{H}]^{+}$ Calcd for $\mathrm{C}_{16} \mathrm{H}_{15} \mathrm{O}_{3}: 255.10212$. Found: 255.10187.

6-Acetoxy-6-(2-vinylbenzyl)cyclohexa-2,4-dien-1-one (7e) To a solution of $\mathbf{6 e}(54 \mathrm{mg}, 0.24 \mathrm{mmol})$ in $\mathrm{AcOH}(1 \mathrm{~mL})$ was added $\mathrm{Pb}(\mathrm{OAc})_{4}(317 \mathrm{mg}, 0.715 \mathrm{mmol})$ at $0{ }^{\circ} \mathrm{C}$, and the reaction temperature was allowed to reach room temperature. After $1 \mathrm{~h}$, the precipitate was filtered off with EtOAc, and the filtrate was washed with saturated aqueous solution of $\mathrm{NaHCO}_{3}$. The organic phase was dried over anhydrous $\mathrm{Na}_{2} \mathrm{SO}_{4}$, filtered, and concentrated in vacuo. The crude product was purified by column chromatography on silica gel (EtOAc/Hexane/1\% triethylammonium acetate (TEA)) to yield 7 e $(15 \mathrm{mg}, 0.055 \mathrm{mmol}$, $23 \%)$ as a yellow oil. Compound $7 \mathrm{e}:{ }^{1} \mathrm{H}-\mathrm{NMR}\left(\mathrm{CDCl}_{3}\right.$, $600 \mathrm{MHz}) \delta: 7.52(1 \mathrm{H}, \mathrm{d}, J=7.8 \mathrm{~Hz}), 7.19(2 \mathrm{H}, \mathrm{d}, J=4.2 \mathrm{~Hz})$, 7.11-7.06 (2H, m), 6.97-6.94 (1H, m), 6.27-6.25 (1H, m), $6.18(1 \mathrm{H}, \mathrm{d}, J=9.6 \mathrm{~Hz}), 6.07(1 \mathrm{H}, \mathrm{d}, J=9.0 \mathrm{~Hz}), 5.63(1 \mathrm{H}, \mathrm{d}$, $J=16.8 \mathrm{~Hz}), 5.23(1 \mathrm{H}, \mathrm{d}, J=10.8 \mathrm{~Hz}), 3.15(1 \mathrm{H}, \mathrm{d}, J=13.8 \mathrm{~Hz})$, $3.06(1 \mathrm{H}, \mathrm{d}, J=13.8 \mathrm{~Hz}), 2.08(3 \mathrm{H}, \mathrm{s}) ;{ }^{13} \mathrm{C}-\mathrm{NMR}\left(\mathrm{CDCl}_{3}\right.$, $150 \mathrm{MHz}) \delta$ : 198.4, 169.3, 141.2, 140.5, 138.3, 135.3, 135.2, $132.3,131.3,127.7,127.1,125.9,123.0,115.8,81.3,40.1,20.5$; 
IR $\left(\mathrm{CHCl}_{3}, \mathrm{~cm}^{-1}\right):$ 2927, 2856, 1739, 1676; HRMS (DART+): $\mathrm{m} / z[\mathrm{M}+\mathrm{H}]^{+}$Calcd for $\mathrm{C}_{17} \mathrm{H}_{17} \mathrm{O}_{3}:$ 269.11777. Found: 269.11855 .

The IMDA Reaction of 7e to 9e (Table 1, Entry 5) A solution of $7 \mathbf{e}(59 \mathrm{mg}, 0.22 \mathrm{mmol})$ in xylenes $(1 \mathrm{~mL})$ was refluxed for $16 \mathrm{~h}$. After cooling to room temperature, the crude products were purified by column chromatography on silica gel (EtOAc/Hexane) to provide the product 9e $(43 \mathrm{mg}, 0.16 \mathrm{mmol}$, 52\%). Compound 9e: $\mathrm{mp}$ : $97.5-98.5^{\circ} \mathrm{C}$ (recryst. from $\mathrm{CH}_{2} \mathrm{Cl}_{2}$ ); ${ }^{1} \mathrm{H}-\mathrm{NMR}\left(\mathrm{CDCl}_{3}, 600 \mathrm{MHz}\right) \delta: 7.14-7.06(4 \mathrm{H}, \mathrm{m}), 6.66(1 \mathrm{H}, \mathrm{t}$, $J=7.2 \mathrm{~Hz}), 6.21(1 \mathrm{H}, \mathrm{t}, J=7.2 \mathrm{~Hz}), 4.28(1 \mathrm{H}, \mathrm{d}, J=15.6), 3.86$ $(1 \mathrm{H}, \mathrm{t}, J=5.4 \mathrm{~Hz}), 3.56(1 \mathrm{H}, \mathrm{t}, J=6.0 \mathrm{~Hz}), 3.15(1 \mathrm{H}, \mathrm{d}, J=16.2$ H), $2.99(1 \mathrm{H}, \mathrm{dd}, J=10.2,4.8 \mathrm{~Hz}), 2.29(1 \mathrm{H}, \mathrm{dd}, J=13.2$, $4.2 \mathrm{~Hz}), 2.12(3 \mathrm{H}, \mathrm{s}), 1.84(1 \mathrm{H}, \mathrm{dd}, J=11.4,12.6 \mathrm{~Hz}) ;{ }^{13} \mathrm{C}-\mathrm{NMR}$ $\left(\mathrm{CDCl}_{3}, 150 \mathrm{MHz}\right) \delta: 203.1,170.4,144.3,139.7,134.9,130.4$, $128.1,126.8,126.6,126.0,80.8,57.0,43.7,38.9,36.3,32.4$, 22.0; IR $\left(\mathrm{CHCl}_{3}, \mathrm{~cm}^{-1}\right): 3024,1736$; HRMS (DART+): $\mathrm{m} / \mathrm{z}$ $[\mathrm{M}+\mathrm{H}]^{+}$Calcd for $\mathrm{C}_{17} \mathrm{H}_{17} \mathrm{O}_{3}: 269.11777$. Found: 269.11805 .

1-(tert-Butyldimethylsilyloxy)-2-(2-iodostyryl)benzene (12) To a cooled suspension of triphenyl(2-vinylbenzyl)phosphonium bromide $(5.19 \mathrm{~g}, 9.28 \mathrm{mmol})$ in THF $(46 \mathrm{~mL})$ at $0{ }^{\circ} \mathrm{C}$ was added potassium tert-butoxide $(1.21 \mathrm{~g}, 10.8 \mathrm{mmol})$ under argon. After $30 \mathrm{~min}$, 2-tert-butyldimethylsiloxybenzaldehyde 10 (1.83 g, $7.73 \mathrm{mmol})$ was added over $10 \mathrm{~min}$. The reaction temperature was warmed to r.t. and the mixture was stirred for $12 \mathrm{~h}$. After adding water $(30 \mathrm{~mL})$ slowly, the aqueous phase was separated and extracted with EtOAc. The combined organic extracts were washed with brine, dried over anhydrous $\mathrm{Na}_{2} \mathrm{SO}_{4}$, filtered, and concentrated in vacuo. The crude product was purified by column chromatography on silica gel (Hexane) to give the product $12(2.77 \mathrm{~g}, 6.34 \mathrm{mmol}$, $82 \%$, a mixture of $(E)$ - and $(Z)-12)$ as a yellow oil. Compound 12: ${ }^{1} \mathrm{H}-\mathrm{NMR}\left(\mathrm{CDCl}_{3}, 600 \mathrm{MHz}, E / Z=5: 1\right.$, data of $(E)-12$ is shown here) $\delta: 7.87(1 \mathrm{H}, \mathrm{d}, J=9.0 \mathrm{~Hz}), 7.69(1 \mathrm{H}, \mathrm{d}, J=7.2 \mathrm{~Hz})$, $7.60(1 \mathrm{H}, \mathrm{d}, J=7.8 \mathrm{~Hz}), 7.37(1 \mathrm{H}, \mathrm{d}, J=10.8 \mathrm{~Hz}), 7.34(1 \mathrm{H}$, dd, $J=7.8,7.8 \mathrm{~Hz}), 7.24(1 \mathrm{H}, \mathrm{d}, J=16.2 \mathrm{~Hz}), 7.17(1 \mathrm{H}, \mathrm{dd}$, $J=6.6,6.6 \mathrm{~Hz}), 7.00(1 \mathrm{H}, \mathrm{dd}, J=7.8,7.8 \mathrm{~Hz}), 6.94(1 \mathrm{H}, \mathrm{dd}$, $J=6.6,6.6 \mathrm{~Hz}), 6.84(1 \mathrm{H}, \mathrm{d}, J=8.4 \mathrm{~Hz}), 1.04(9 \mathrm{H}, \mathrm{s}), 0.24$ $(6 \mathrm{H}, \mathrm{s}) ;{ }^{13} \mathrm{C}-\mathrm{NMR}\left(\mathrm{CDCl}_{3}, 150 \mathrm{MHz}\right.$, data of $(E)-\mathbf{1 2}$ is shown here) $\delta: 153.3,140.7,139.6,131.9,128.9,128.7,128.4,126.7$, $126.4,126.0,121.6,119.7,100.5,25.8,18.3,-4.1$; IR (neat, $\mathrm{cm}^{-1}$ ):1597, 1252, 1011; HRMS (DART+): $\mathrm{m} / z[\mathrm{M}+\mathrm{H}]^{+}$Calcd for $\mathrm{C}_{20} \mathrm{H}_{26}$ IOSi: 437.07976. Found: 437.08039.

1-(tert-Butyldimethylsilyloxy)-2-(2-iodophenethyl)benzene (13) Tosylhydrazide $(50 \mathrm{mg}, 0.12 \mathrm{mmol})$ and sodium acetate $(47 \mathrm{mg}, 0.57 \mathrm{mmol})$ were added to a solution of $\mathbf{1 2}$ $(50 \mathrm{mg}, 0.12 \mathrm{mmol})$ in EtOH $(0.5 \mathrm{~mL})$. The mixture was refluxed for $2 \mathrm{~h}$ with stirring. When the reaction was complete, the mixture was cooled to room temperature. The mixture was diluted with $\mathrm{Et}_{2} \mathrm{O}(5 \mathrm{~mL})$ and washed with saturated solution of $\mathrm{NaHCO}_{3}$ and brine. The organic phase was dried over anhydrous $\mathrm{Na}_{2} \mathrm{SO}_{4}$, filtered, and concentrated under reduced pressure. The crude product was purified by column chromatography on silica gel (EtOAc/hexane) to give $\mathbf{1 3}$ (45.6 mg, $0.104 \mathrm{mmol}, 90 \%$ ) as a yellow oil. Compound 13: ${ }^{1} \mathrm{H}-\mathrm{NMR}\left(\mathrm{CDCl}_{3}, 600 \mathrm{MHz}\right) \delta: 7.82(1 \mathrm{H}, \mathrm{d}, J=7.8 \mathrm{~Hz}), 7.23$ $(1 \mathrm{H}, \mathrm{dd}, J=7.2,7.2 \mathrm{~Hz}), 7.14(1 \mathrm{H}, \mathrm{d}, J=6.0 \mathrm{~Hz}), 7.13(1 \mathrm{H}, \mathrm{d}$, $J=7.8 \mathrm{~Hz}), 6.89-6.84(2 \mathrm{H}, \mathrm{m}), 6.81(1 \mathrm{H}, \mathrm{d}, J=7.8 \mathrm{~Hz}), 2.98$ (2H, dd, $J=10.8,9.0 \mathrm{~Hz}), 2.87(2 \mathrm{H}, \mathrm{dd}, J=10.8,9.0 \mathrm{~Hz}), 1.03$ $(9 \mathrm{H}, \mathrm{s}), 0.26(6 \mathrm{H}, \mathrm{s}) ;{ }^{13} \mathrm{C}-\mathrm{NMR}\left(\mathrm{CDCl}_{3}, 150 \mathrm{MHz}\right) \delta: 153.6$, $144.5,139.4,131.7,130.4,129.4,128.4,128.2,127.7,127.0$, $120.1,118.4,100.8,41.2,30.9,25.9,18.3,-4.1$; IR (neat, $\mathrm{cm}^{-1}$ ): 1252, 1011; HRMS (DART+): $\mathrm{m} / z[\mathrm{M}+\mathrm{H}]^{+}$Calcd for $\mathrm{C}_{20} \mathrm{H}_{28}$ IOSi: 439.09541. Found: 439.09442.

3-(2-(2-((tert-Butyldimethylsilyl)oxy)phenethyl)phenyl)1-phenyl-1H-pyrrole-2,5-dione (14) A dry $30 \mathrm{~mL}$ flask containing a magnetic stirring bar was charged with $\mathbf{1 3}$ (900 mg, $2.05 \mathrm{mmol}), \mathrm{Pd}(\mathrm{OAc})_{2}$ (92 mg, $0.41 \mathrm{mmol}$ ), DPEphos (221 mg, $0.410 \mathrm{mmol}), \mathrm{N}$-phenylmaleimide $(1.78 \mathrm{~g}, 2.05 \mathrm{mmol})$, KOAc $(604 \mathrm{mg}, 6.15 \mathrm{mmol})$ and dry ethylene carbonate $(5.4 \mathrm{~g})$. The mixture was stirred at $60^{\circ} \mathrm{C}$ for $6 \mathrm{~h}$, and the mixture was cooled to room temperature. The crude product was purified by column chromatography on silica gel (EtOAc/Hexane) to give $14(259 \mathrm{mg}, 0.59 \mathrm{mmol}, 29 \%)$ as a yellow oil. Compound 14: ${ }^{1} \mathrm{H}-\mathrm{NMR}\left(\mathrm{CDCl}_{3}, 600 \mathrm{MHz}\right) \delta$ : $7.48(2 \mathrm{H}, \mathrm{dd}, J=9.0$, $9.0 \mathrm{~Hz}), 7.41-7.28(7 \mathrm{H}, \mathrm{m}), 7.07-7.04(1 \mathrm{H}, \mathrm{m}), 6.82-6.75(3 \mathrm{H}$, m), $3.03(2 \mathrm{H}, \mathrm{t}, J=7.2 \mathrm{~Hz}), 2.90(2 \mathrm{H}, \mathrm{t}, J=7.2 \mathrm{~Hz}), 0.99(9 \mathrm{H}$, s), $0.21(6 \mathrm{H}, \mathrm{s}) ;{ }^{13} \mathrm{C}-\mathrm{NMR}\left(\mathrm{CDCl}_{3}, 150 \mathrm{MHz}\right) \delta: 169.2,169.1$, $153.7,145.7,141.3,131.7,131.3,130.6,130.40,130.35,130.12$, $130.09,129.6,129.0,128.4,128.2,128.0,127.6,127.55,127.46$, 126.03, 125.91, 33.4, 32.6, 29.7, 25.8, 18.2, -4.1; IR $\left(\mathrm{CHCl}_{3}\right.$, $\left.\mathrm{cm}^{-1}\right): 3473,1768,1714,1623,1598,1502,1257$; HRMS (DART+): $m / z[\mathrm{M}+\mathrm{H}]^{+}$Calcd for $\mathrm{C}_{30} \mathrm{H}_{34} \mathrm{NO}_{3} \mathrm{Si}: 484.23079$. Found: 484.23058 .

3-(2-(2-Hydroxyphenethyl)phenyl)-1-phenyl-1 H-pyrrole-2,5-dione (6f) To a solution of $\mathbf{1 4}(50 \mathrm{mg}, 0.10 \mathrm{mmol})$ in THF $(1 \mathrm{~mL})$ was added pyridine $(0.15 \mathrm{~mL})$ and HF-pyridine $(0.15 \mathrm{~mL})$ at $0{ }^{\circ} \mathrm{C}$. The solution was stirred at $0{ }^{\circ} \mathrm{C}$ for $3 \mathrm{~h}$. The reaction mixture was diluted with EtOAc and $\mathrm{H}_{2} \mathrm{O}$. The organic phase was washed with a saturated aqueous solution of $\mathrm{NH}_{4} \mathrm{Cl}$, a saturated aqueous solution of $\mathrm{NaHCO}_{3}$, and brine. After the organic phase was concentrated under reduced pressure, the crude product was purified by column chromatography on silica gel (EtOAc/hexane) to yield 6f $(35 \mathrm{mg}$, $0.095 \mathrm{mmol}, 95 \%)$ as a yellow oil. Compound 6f: ${ }^{1} \mathrm{H}-\mathrm{NMR}$ $\left(\mathrm{CDCl}_{3}, 600 \mathrm{MHz}\right) \delta: 7.49(2 \mathrm{H}, \mathrm{dd}, J=9.0,9.0 \mathrm{~Hz}), 7.45-7.37$ $(6 \mathrm{H}, \mathrm{m}), 7.33-7.30(1 \mathrm{H}, \mathrm{m}), 7.07(1 \mathrm{H}, \mathrm{dd}, J=9.0,9.0 \mathrm{~Hz}), 7.00$ $(1 \mathrm{H}, \mathrm{dd}, J=7.2,1.8 \mathrm{~Hz}), 6.82(1 \mathrm{H}, \mathrm{dd}, J=6.6,6.6 \mathrm{~Hz}), 6.69$ $(1 \mathrm{H}, \mathrm{s}), 6.69(1 \mathrm{H}, \mathrm{d}, J=6.6 \mathrm{~Hz}), 5.00(1 \mathrm{H}, \mathrm{s}), 3.00(2 \mathrm{H}, \mathrm{dd}$, $J=10.2,9.0 \mathrm{~Hz}), 2.90(2 \mathrm{H}, \mathrm{dd}, J=10.8,9.0 \mathrm{~Hz}) ;{ }^{13} \mathrm{C}-\mathrm{NMR}$ $\left(\mathrm{CDCl}_{3}, 150 \mathrm{MHz}\right) \delta: 169.7,169.6,153.7,145.5,141.3,131.6$, $130.7,130.45,130.41,130.3,129.1,128.6,128.0,127.8,127.7$, 127.1, 126.2, 126.0, 120.8, 115.3, 34.2, 33.0; IR $\left(\mathrm{CHCl}_{3}, \mathrm{~cm}^{-1}\right)$ : 3588, 3473, 3286, 1770, 1712, 1596, 1502; HRMS (DART+): $m / z \quad[\mathrm{M}+\mathrm{H}]^{+}$Calcd for $\mathrm{C}_{24} \mathrm{H}_{20} \mathrm{NO}_{3}:$ 370.14432. Found: 370.14448 .

The Wessely Oxidation of $6 f$ to $7 f$ (Chart 7) To a solution of $\mathbf{6 f}(98 \mathrm{mg}, 0.26 \mathrm{mmol})$ in $\mathrm{AcOH}(4 \mathrm{~mL})$ was added $\mathrm{Pb}(\mathrm{OAc})_{4}(235 \mathrm{mg}, \quad 0.529 \mathrm{mmol})$ at $0{ }^{\circ} \mathrm{C}$, and the reaction temperature was allowed to reach room temperature. After $30 \mathrm{~min}$, the precipitate was filtered off with EtOAc, and the filtrate was washed with saturated aqueous solution of $\mathrm{NaHCO}_{3}$. The organic phase was dried over anhydrous $\mathrm{MgSO}_{4}$, and concentrated in vacuo. The crude product was purified by column chromatography on silica gel (EtOAc/Hexane) to yield 7f $(39 \mathrm{mg}, 0.090 \mathrm{mmol}, 34 \%)$ as a yellow oil. Compound 7f: ${ }^{1} \mathrm{H}-\mathrm{NMR}\left(\mathrm{CDCl}_{3}, 600 \mathrm{MHz}\right) \delta: 7.52-7.50(2 \mathrm{H}, \mathrm{m}), 7.47-7.45$ $(2 \mathrm{H}, \mathrm{m}), 7.41-7.39$ (3H, m), 7.33-7.29 (2H, m), $6.77(1 \mathrm{H}, \mathrm{s})$, 6.31-6.26 (2H, m), $6.15(1 \mathrm{H}, \mathrm{d}, J=10.2 \mathrm{~Hz}), 2.82(1 \mathrm{H}$, ddd, $J=13.2,13.2,4.8 \mathrm{~Hz}), 2.73(1 \mathrm{H}, \mathrm{ddd}, J=13.2,13.2,4.8 \mathrm{~Hz})$, 2.14-2.07 (1H, m), $2.11(3 \mathrm{H}, \mathrm{s}) ;{ }^{13} \mathrm{C}-\mathrm{NMR}\left(\mathrm{CDCl}_{3}, 150 \mathrm{MHz}\right)$ $\delta: 169.5,169.4,169.0,145.6,141.0,140.5,140.0,130.6,130.5$, $130.0,129.1,128.6,128.0,127.9,126.8,126.6,126.1,123.0$, 
81.1, 39.0, 26.5, 20.4; IR $\left(\mathrm{CHCl}_{3}, \mathrm{~cm}^{-1}\right): 3473,1770,1737$, 1716, 1675, 1502, 1390; HRMS (DART+): $m / z[\mathrm{M}+\mathrm{H}]^{+}$Calcd for $\mathrm{C}_{26} \mathrm{H}_{22} \mathrm{NO}_{5}$ : 428.14980. Found: 428.15020 .

The IMDA Reaction of $7 f$ to 9 f (Chart 7) Compound 7f $(38 \mathrm{mg}, 0.089 \mathrm{mmol})$ was heated at $170^{\circ} \mathrm{C}$ in a vial without any solvent for $3.5 \mathrm{~h}$. After cooling to room temperature, the crude products were purified by column chromatography on silica gel (EtOAc/Hexane) to provide the product 9f (20 mg, $0.047 \mathrm{mmol}, 52 \%$ ). Compound 9f: $\mathrm{mp}: 284.0-285.0^{\circ} \mathrm{C}$ (recryst. from $\left.\mathrm{CH}_{2} \mathrm{Cl}_{2}\right)$; ${ }^{1} \mathrm{H}-\mathrm{NMR}\left(\mathrm{CDCl}_{3}, 600 \mathrm{MHz}\right) \delta$ : 8.61 $(1 \mathrm{H}, \mathrm{d}, J=10.8 \mathrm{~Hz}), 7.49-7.47(2 \mathrm{H}, \mathrm{m}), 7.44-7.41(1 \mathrm{H}, \mathrm{m})$, $7.34(1 \mathrm{H}, \mathrm{dd}, J=7.2,7.2 \mathrm{~Hz}), 7.27-7.20(3 \mathrm{H}, \mathrm{m}), 7.13(1 \mathrm{H}$, $\mathrm{d}, J=7.8 \mathrm{~Hz}), 6.56(1 \mathrm{H}, \mathrm{dd}, J=6.6,6.6 \mathrm{~Hz}), 6.34(1 \mathrm{H}, \mathrm{ddd}$, $J=7.8,7.8,1.2 \mathrm{~Hz}), 5.06(1 \mathrm{H}, \mathrm{ddd}, J=5.1,5.1,1.8 \mathrm{~Hz}), 4.76$ $(1 \mathrm{H}, \mathrm{d}, J=4.2 \mathrm{~Hz}), 3.79(1 \mathrm{H}, \mathrm{d}, J=6.0 \mathrm{~Hz}), 3.70-3.64(1 \mathrm{H}, \mathrm{m})$, $3.17(1 \mathrm{H}, \mathrm{ddd}, J=12.0,6.6,2.4 \mathrm{~Hz}), 2.92(1 \mathrm{H}, \mathrm{ddd}, J=20.8$, 6.6, 2.4 Hz), $2.73(1 \mathrm{H}, \mathrm{ddd}, J=13.2,13.2,4.8 \mathrm{~Hz}), 2.36(1 \mathrm{H}$, ddd, $J=13.2,13.2,6.0 \mathrm{~Hz}), 2.00(3 \mathrm{H}, \mathrm{s}) ;{ }^{13} \mathrm{C}-\mathrm{NMR}\left(\mathrm{CDCl}_{3}\right.$, $150 \mathrm{MHz}) \delta: 201.0,176.0,174.0,169.7,136.5,136.3,134.6$, $133.9,131.5,129.3,129.1,128.9,128.5,128.1,126.5,126.3$, $79.6,60.3,51.4,43.6,39.2,34.3,33.9,22.1$; IR $\left(\mathrm{CHCl}_{3}\right.$, $\left.\mathrm{cm}^{-1}\right): 3477,1779,1737,1712,1498,1386$; HRMS (DART+): $m / z \quad[\mathrm{M}+\mathrm{H}]^{+}$Calcd for $\mathrm{C}_{26} \mathrm{H}_{22} \mathrm{NO}_{5}:$ 428.14980. Found: 428.14995 .

tert-Butyl(2-(2-iodo-3,4,5-trimethoxystyryl)phenoxy)dimethylsilane (16) To triphenylphosphine $(2.1 \mathrm{~g}, 11 \mathrm{mmol})$ in a flask under a nitrogen atmosphere and heated to $100^{\circ} \mathrm{C}$ in oil bath was added 1-(bromomethyl)-2-iodo-3,4,5-trimethoxybenzene $(1.9 \mathrm{~g}, 4.9 \mathrm{mmol})$. After $10 \mathrm{~min}$, to this was added $\mathrm{CH}_{2} \mathrm{Cl}_{2}$, and the mixture was concentrated, then filtered and washed extensively with EtOAc and $\mathrm{CHCl}_{3}$ to yield the phosphonium salt $(2.8 \mathrm{~g}, 4.8 \mathrm{mmol}, 97 \%)$ as a white solid. mp: $224.0-225.0^{\circ} \mathrm{C}$ (recryst. from $\left.\mathrm{CH}_{2} \mathrm{Cl}_{2}\right) ;{ }^{1} \mathrm{H}-\mathrm{NMR}\left(\mathrm{CDCl}_{3}\right.$, $600 \mathrm{MHz}) \delta: 7.56-7.89(15 \mathrm{H}, \mathrm{m}), 7.16(1 \mathrm{H}, \mathrm{brs}), 5.54-5.79(2 \mathrm{H}$, brm), $3.84(3 \mathrm{H}$, brd, $J=1.4 \mathrm{~Hz}), 3.72(3 \mathrm{H}$, brd, $J=1.4 \mathrm{~Hz})$, $3.58(3 \mathrm{H}$, brd, $J=2.1 \mathrm{~Hz}) ;{ }^{13} \mathrm{C}-\mathrm{NMR}\left(\mathrm{CDCl}_{3}, 150 \mathrm{MHz}\right) \delta$ : $142.2,135.2,134.5,130.2,125.6,117.5,117.0,112.3,92.8$, 61.1, 60.6, 56.4, 35.6; IR (neat, $\mathrm{cm}^{-1}$ ):2939, 2854, 1482, 1483; HRMS (DART+): $m / z \quad\left[\mathrm{M}-\mathrm{C}_{10} \mathrm{H}_{12} \mathrm{O}_{3} \mathrm{I}\right]^{+}$Calcd for $\mathrm{C}_{18} \mathrm{H}_{16} \mathrm{P}$ : 263.0990. Found: 263.0980 .

To a cooled suspension of a phosphonium bromide $(2.0 \mathrm{~g}$, $3.1 \mathrm{mmol})$ in THF $(15 \mathrm{~mL})$ was added potassium tert-butoxide (404 mg, $3.60 \mathrm{mmol}$ ) under nitrogen at $0^{\circ} \mathrm{C}$. After stirring the mixture for $30 \mathrm{~min}$, 2-tert-butyldimethylsiloxybenzaldehyde $10(607 \mathrm{mg}, 2.57 \mathrm{mmol})$ was added over $10 \mathrm{~min}$. The reaction temperature was warmed to room temperature and the mixture was stirred for $12 \mathrm{~h}$. After adding water $(30 \mathrm{~mL})$, the aqueous phase was separated and extracted with EtOAc. The combined organic extracts were washed with brine, dried over anhydrous $\mathrm{Na}_{2} \mathrm{SO}_{4}$, and concentrated in vacuo. The crude product was purified by column chromatography on silica gel (Hexane) to give $16(1.29 \mathrm{~g}, 2.44 \mathrm{mmol}, 95 \%$, a mixture of $(E)-16$ and $(Z)-16)$ as a colourless oil. Compound 16: ${ }^{1} \mathrm{H}-\mathrm{NMR}$ $\left(\mathrm{CDCl}_{3}, 400 \mathrm{MHz}\right) \delta: 7.71(0.4 \mathrm{H}, \mathrm{d}, J=8.0 \mathrm{~Hz}), 7.32(0.8 \mathrm{H}$, s), $7.17(0.4 \mathrm{H}, \mathrm{t}, J=8.0 \mathrm{~Hz}), 6.96-7.11(2.0 \mathrm{H}, \mathrm{m}), 6.66-6.86$ $(2.2 \mathrm{H}, \mathrm{m}), 6.51-6.60(1.2 \mathrm{H}, \mathrm{m}), 3.90(5.4 \mathrm{H}, \mathrm{s}), 3.87(1.8 \mathrm{H}, \mathrm{s})$, $3.42(1.8 \mathrm{H}, \mathrm{s}), 1.06(3.6 \mathrm{H}, \mathrm{s}), 1.02(5.4 \mathrm{H}, \mathrm{s}), 0.25(2.4 \mathrm{H}, \mathrm{s}), 0.24$ $(\mathrm{s}, 3.6 \mathrm{H}) ;{ }^{13} \mathrm{C}-\mathrm{NMR}\left(\mathrm{CDCl}_{3}, 150 \mathrm{MHz}\right) \delta: 153.8,153.6,153.1$, $153.0,141.6,141.0,136.5,133.1,131.9,130.5,128.9,128.5$, $128.2,127.9,127.1,126.1,125.6,121.6,120.9,119.5,109.6$, $104.9,88.9,87.8,61.1,61.0,60.8,60.7,55.9,55.6,25.9,25.8$,
18.3, 4.08, -4.08, -4.22; IR (neat, $\mathrm{cm}^{-1}$ ): 2932, 2856, 1596, 1255; HRMS (DART +$): m / z[\mathrm{M}+\mathrm{H}]^{+}$Calcd for $\mathrm{C}_{23} \mathrm{H}_{32} \mathrm{IO}_{4} \mathrm{Si}$ : 527.1115. Found: 527.1106 .

tert-Butyl(2-(2-iodo-3,4,5-trimethoxyphenethyl)phenoxy)dimethylsilane (17) Tosylhydrazide $(1.04 \mathrm{~g}, 5.58 \mathrm{mmol})$ and sodium acetate $(1.21 \mathrm{~g}, 14.0 \mathrm{mmol})$ were added to a solution of $16(1.47 \mathrm{~g}, 2.79 \mathrm{mmol})$ in EtOH $(13 \mathrm{~mL})$, and the mixture was refluxed for $4 \mathrm{~h}$. The reaction temperature was cooled to room temperature, and the mixture was diluted with $\mathrm{Et}_{2} \mathrm{O}$. The mixture was washed with saturated aqueous solution of $\mathrm{NaHCO}_{3}$ and brine. The organic phase was dried over anhydrous $\mathrm{Na}_{2} \mathrm{SO}_{4}$, and concentrated under reduced pressure. The products were purified by column chromatography on silica gel (EtOAc/Hexane) to give $17(1.34 \mathrm{~g}, 2.54 \mathrm{mmol}, 91 \%)$ as a colourless oil. Compound 17: ${ }^{1} \mathrm{H}-\mathrm{NMR}\left(\mathrm{CDCl}_{3}, 600 \mathrm{MHz}\right)$ $\delta$ : 7.13-7.18 $(1 \mathrm{H}, \mathrm{m}), 7.06-7.11(\mathrm{~m}, 1 \mathrm{H}), 6.85-6.90(\mathrm{~m}, 1 \mathrm{H})$, 6.79-6.83 (1H, m), $6.51(1 \mathrm{H}, \mathrm{s}), 3.88(3 \mathrm{H}, \mathrm{s}), 3.86(3 \mathrm{H}, \mathrm{s})$, $3.74(3 \mathrm{H}, \mathrm{s}), 2.95-3.02(2 \mathrm{H}, \mathrm{m}), 2.82-2.89(2 \mathrm{H}, \mathrm{m}), 1.05(9 \mathrm{H}$, s), $0.27(6 \mathrm{H}, \mathrm{s}) ;{ }^{13} \mathrm{C}-\mathrm{NMR}\left(\mathrm{CDCl}_{3}, 150 \mathrm{MHz}\right) \delta: 153.6,153.3$, $153.0,140.3,131.7,130.6,127.0,121.1,118.4,108.8,88.1,61.0$, 60.7, 55.9, 41.5, 31.0, 25.9, 18.3, -4.05; IR $\left(\mathrm{CHCl}_{3}, \mathrm{~cm}^{-1}\right)$ : 2932, 2856, 1252; HRMS (DART+): $m / z[\mathrm{M}+\mathrm{H}]^{+}$Calcd for $\mathrm{C}_{23} \mathrm{H}_{34} \mathrm{IO}_{4}$ Si: 529.1271. Found: 529.1270 .

6-(2-((tert-Butyldimethylsilyl)oxy)phenethyl)-2,3,4-trimethoxybenzaldehyde (18) To a solution of 17 (500 mg, $0.95 \mathrm{mmol})$ in THF $(10 \mathrm{~mL})$ was added a solution of $n$-butyllithium $(1.62 \mathrm{M}$ in hexane, $1.46 \mathrm{~mL}, 2.37 \mathrm{mmol})$ dropwise at $-78^{\circ} \mathrm{C}$. After stirring for $30 \mathrm{~min}$ at $-78^{\circ} \mathrm{C}$, anhydrous DMF $(0.73 \mathrm{~mL}, 9.5 \mathrm{mmol})$ was added dropwise. The reaction mixture was stirred for another $1 \mathrm{~h}$ at $-78^{\circ} \mathrm{C}$. The reaction was warmed to room temperature and stirred for another $2 \mathrm{~h}$, followed by the addition of $3 \mathrm{M} \mathrm{HCl}(3 \mathrm{~mL})$. The resulting mixture was extracted with $\mathrm{Et}_{2} \mathrm{O}$, and the organic extracts were washed with brine, dried over anhydrous $\mathrm{Na}_{2} \mathrm{SO}_{4}$, and concentrated under reduced pressure. The crude product was purified by column chromatography on silica gel (EtOAc/Hexane) to afford compound $\mathbf{1 8}$ which was not completely pure. The crude product $\mathbf{1 8}$ was used without further purification in the next step.

(E)-tert-Butyldimethyl(2-(3,4,5-trimethoxy-2-(2-nitrovinyl)phenethyl)phenoxy)silane (19) The mixture of the crude 18, nitromethane $(3.62 \mathrm{~g}, 59.4 \mathrm{mmol})$ and ammonium acetate $(15 \mathrm{mg}, 0.19 \mathrm{mmol})$ was stirred at $100^{\circ} \mathrm{C}$ for $3 \mathrm{~h}$. After cooling the reaction mixture to room temperature, the mixture was concentrated, and then $\mathrm{H}_{2} \mathrm{O}$ and dichloromethane were added. The mixture was washed with $\mathrm{H}_{2} \mathrm{O}, 1 \mathrm{~N}$ hydrochloric acid and brine, dried over $\mathrm{Na}_{2} \mathrm{SO}_{4}$, and concentrated under reduced pressure. The crude product was purified by column chromatography on silica gel $\left(\mathrm{CH}_{2} \mathrm{Cl}_{2} /\right.$ hexane $)$ to yield 19 as a yellow solid $(179 \mathrm{mg}, 0.38 \mathrm{mmol}, 40 \%$ yield for two steps). Compound 19: mp: $73.5-74.5^{\circ} \mathrm{C}$ (recryst. from $\mathrm{CH}_{2} \mathrm{Cl}_{2}$ ); ${ }^{1} \mathrm{H}-\mathrm{NMR}\left(\mathrm{CDCl}_{3}, 600 \mathrm{MHz}\right) \delta: 8.11(1 \mathrm{H}, \mathrm{d}, J=13.4 \mathrm{~Hz}), 7.92$ $(1 \mathrm{H}, \mathrm{d}, J=13.4 \mathrm{~Hz}), 7.07(1 \mathrm{H}, \mathrm{t}, J=6.9 \mathrm{~Hz}), 6.97(1 \mathrm{H}, \mathrm{d}$, $J=6.5 \mathrm{~Hz}), 6.83(1 \mathrm{H}, \mathrm{t}, J=7.4 \mathrm{~Hz}), 6.78(1 \mathrm{H}, \mathrm{d}, J=7.9 \mathrm{~Hz})$, $6.45(1 \mathrm{H}, \mathrm{s}), 3.91(3 \mathrm{H}, \mathrm{s}), 3.85(3 \mathrm{H}, \mathrm{s}), 3.80(3 \mathrm{H}, \mathrm{s}), 3.03(3 \mathrm{H}$, $\mathrm{t}, J=7.6 \mathrm{~Hz}), 2.86(2 \mathrm{H}, \mathrm{t}, J=7.6 \mathrm{~Hz}), 1.03(9 \mathrm{H}, \mathrm{s}), 0.26(6 \mathrm{H}$, $\mathrm{s}) ;{ }^{13} \mathrm{C}-\mathrm{NMR}\left(\mathrm{CDCl}_{3}, 150 \mathrm{MHz}\right) \delta: 156.0,154.6,153.6,141.1$, $140.6,138.0,132.2,130.7,130.6,127.4,121.2,118.4,115.3$, $109.3,60.9,60.4,55.8,34.4,32.9,25.8,18.2,-4.13$; IR $\left(\mathrm{CHCl}_{3}, \mathrm{~cm}^{-1}\right): 2932,2856,1589,1261 ; \mathrm{HRMS}$ (DART+): $\mathrm{m} / \mathrm{z}$ $[\mathrm{M}+\mathrm{H}]^{+}$Calcd for $\mathrm{C}_{24} \mathrm{H}_{36} \mathrm{NO}_{6} \mathrm{Si}: 474.23119$. Found: 474.2310. 
(E)-2-(3,4,5-Trimethoxy-2-(2-nitrovinyl)phenethyl)phenol (6g) To a solution of $19(140 \mathrm{mg}, 0.30 \mathrm{mmol})$ in THF $(6 \mathrm{~mL})$ was added TBAF $(1.0 \mathrm{M}$ solution in THF, $0.36 \mathrm{~mL}$, $0.36 \mathrm{mmol})$ dropwise at $0{ }^{\circ} \mathrm{C}$. The solution was stirred at $0{ }^{\circ} \mathrm{C}$ for $30 \mathrm{~min}$. Water was added to the reaction mixture, and the resulting mixture was extracted with $\mathrm{Et}_{2} \mathrm{O}$. The organic extracts were washed with brine, dried over anhydrous $\mathrm{Na}_{2} \mathrm{SO}_{4}$, and concentrated under reduced pressure. The crude product was purified by column chromatography on silica gel (EtOAc/ Hexane) to yield $\mathbf{6 g}(104 \mathrm{mg}, 0.029 \mathrm{mmol}, 98 \%)$ as a yellow oil. Compound 6g: ${ }^{1} \mathrm{H}-\mathrm{NMR}\left(\mathrm{CDCl}_{3}, 600 \mathrm{MHz}\right) \delta$ : $8.27(1 \mathrm{H}$, d, $J=13.1 \mathrm{~Hz}), 7.94(1 \mathrm{H}, \mathrm{d}, J=13.4 \mathrm{~Hz}), 7.05-7.10(1 \mathrm{H}, \mathrm{m})$, $6.94(1 \mathrm{H}, \mathrm{d}, J=7.6 \mathrm{~Hz}), 6.80(1 \mathrm{H}, \mathrm{t}, J=7.4 \mathrm{~Hz}), 6.73(1 \mathrm{H}, \mathrm{d}$, $J=7.9 \mathrm{~Hz}), 6.59(1 \mathrm{H}, \mathrm{s}), 5.18(1 \mathrm{H}, \mathrm{brs}), 3.90(6 \mathrm{H}, \mathrm{s}), 3.86(3 \mathrm{H}$, s), $3.06(2 \mathrm{H}, \mathrm{t}, J=7.9 \mathrm{~Hz}), 2.86(2 \mathrm{H}, \mathrm{t}, J=7.9 \mathrm{~Hz}) ;{ }^{13} \mathrm{C}-\mathrm{NMR}$ $\left(\mathrm{CDCl}_{3}, 150 \mathrm{MHz}\right) \delta: 156.2,154.7,153.7,141.5,140.7,138.0$, 132.9, 130.6, 127.7, 126.8, 120.8, 115.7, 115.1, 109.3, 60.9, 60.4, 56.0, 34.3, 33.7; IR $\left(\mathrm{CHCl}_{3}, \mathrm{~cm}^{-1}\right): 3444,2938,2850,1589$; HRMS (DART +$): m / z[\mathrm{M}+\mathrm{H}]^{+}$Calcd for $\mathrm{C}_{19} \mathrm{H}_{22} \mathrm{NO}_{6} \mathrm{Si}$ : 360.14471. Found: 360.14454 .

The Wessely Oxidation of $6 \mathrm{~g}$ to $7 \mathrm{~g}$ (Table 2, Entry 1) Compound 6g $(300 \mathrm{mg}, 0.84 \mathrm{mmol})$ in $\mathrm{AcOH}(5 \mathrm{~mL})$ was added to a solution of $\mathrm{Pb}(\mathrm{OAc})_{4}(556 \mathrm{mg}, 1.25 \mathrm{mmol})$ in $\mathrm{AcOH}$ $(5 \mathrm{~mL})$ at $0{ }^{\circ} \mathrm{C}$. The reaction temperature was warmed to room temperature, and the mixture was stirred for $2 \mathrm{~h}$. The precipitate was filtered off with AcOEt and the filtrate was wash with saturated aqueous solution of $\mathrm{NaHCO}_{3}$. The organic phase was washed with brine, dried over anhydrous $\mathrm{Na}_{2} \mathrm{SO}_{4}$, and concentrated in vacuo. The crude product was purified by column chromatography on silica gel (EtOAc/hexane) to yield $\mathbf{7 g}$ (151 mg, $0.36 \mathrm{mmol}, 43 \%$ ) as a yellow amorphous. Compound 7g: ${ }^{1} \mathrm{H}-\mathrm{NMR}\left(\mathrm{CDCl}_{3}, 600 \mathrm{MHz}\right) \delta: 8.11(1 \mathrm{H}, \mathrm{d}, J=13.2 \mathrm{~Hz})$, $7.98(1 \mathrm{H}, \mathrm{d}, J=12.6 \mathrm{~Hz}), 7.04-7.09(1 \mathrm{H}, \mathrm{m}), 6.51(1 \mathrm{H}, \mathrm{s})$, 6.44-6.48 (1H, m), 6.38-6.42 (1H, m), $6.24(1 \mathrm{H}, \mathrm{d}, J=9.6 \mathrm{~Hz})$, $3.94(3 \mathrm{H}, \mathrm{s}), 3.89(3 \mathrm{H}, \mathrm{s}), 3.84(3 \mathrm{H}, \mathrm{s}), 2.83-2.93(1 \mathrm{H}, \mathrm{m})$, 2.74-2.82 (1H, m), 2.19 (3H, s), 1.99-2.01 (1H, m), 1.82-1.92 $(1 \mathrm{H}, \mathrm{m}) ;{ }^{13} \mathrm{C}-\mathrm{NMR}\left(\mathrm{CDCl}_{3}, 150 \mathrm{MHz}\right) \delta: 198.1,169.6,156.4$, $155.0,140.9,140.8,139.8,138.5,131.8,126.8,123.5,114.9$, $109.2,80.9,60.9,60.5,56.1,39.6,27.5,20.4 ; \mathrm{IR}\left(\mathrm{CHCl}_{3}, \mathrm{~cm}^{-1}\right)$ : 2927, 2854, 1749, 1716, 1595; HRMS (DART+): $m / z[\mathrm{M}+\mathrm{H}]^{+}$ Calcd for $\mathrm{C}_{21} \mathrm{H}_{24} \mathrm{NO}_{8}$ : 418.1502. Found: 418.1507.

The IMDA Reaction of $\mathbf{7 g}$ to $\mathbf{9 g}$ (Table 2, Entry 3) A solution of $7 \mathrm{~g}(39 \mathrm{mg}, 0.092 \mathrm{mmol})$ in 2,2,2-trifluoroethanol $(1 \mathrm{~mL})$ was heated in a vial at $130^{\circ} \mathrm{C}$ under microwave irradiation for $18 \mathrm{~h}$. After concentration, the crude product was purified by column chromatography on silica gel (EtOAc/ $\left.\mathrm{CH}_{2} \mathrm{Cl}_{2}\right)$ to provide $9 \mathrm{~g}(9.6 \mathrm{mg}, 0.023 \mathrm{mmol}, 25 \%)$ as a brown solid. Compound 9g: mp: $84.0-85.5^{\circ} \mathrm{C}$ (recryst. from $\mathrm{CH}_{2} \mathrm{Cl}_{2}$ ); ${ }^{1} \mathrm{H}-\mathrm{NMR}\left(\mathrm{CDCl}_{3}, 600 \mathrm{MHz}\right) \delta: 6.38(1 \mathrm{H}, \mathrm{t}, J=7.2 \mathrm{~Hz}), 6.35$ $(1 \mathrm{H}, \mathrm{s}), 6.31(1 \mathrm{H}, \mathrm{t}, J=6.9 \mathrm{~Hz}), 5.81(1 \mathrm{H}, \mathrm{d}, J=3.6 \mathrm{~Hz}), 5.21$ $(1 \mathrm{H}, \mathrm{s}), 4.89(1 \mathrm{H}, \mathrm{d}, J=4.2 \mathrm{~Hz}), 3.97(3 \mathrm{H}, \mathrm{s}), 3.86(3 \mathrm{H}, \mathrm{s})$, $3.83-3.89(1 \mathrm{H}, \mathrm{m}), 3.82(3 \mathrm{H}, \mathrm{s}), 3.39(1 \mathrm{H}, \mathrm{t}, J=5.2 \mathrm{~Hz})$, 3.23-3.35 (1H, m), 3.00-3.09 (1H, m), 2.71-2.81 (1H, m), 2.24-2.33 (1H, m), $2.02(3 \mathrm{H}, \mathrm{s}) ;{ }^{13} \mathrm{C}-\mathrm{NMR}\left(\mathrm{CDCl}_{3}, 150 \mathrm{MHz}\right)$ $\delta: 202.3,170.2,152.8,152.0,141.8,133.1,131.9,129.0,121.8$, $112.3,82.9,79.9,61.8,61.1,56.1,53.7,42.5,36.1,33.3,33.0$, 22.5; IR $\left(\mathrm{CHCl}_{3}, \quad \mathrm{~cm}^{-1}\right): 2940,2838,1736,1552$; HRMS (DART+): $\mathrm{m} / \mathrm{z}[\mathrm{M}+\mathrm{H}]^{+}$Calcd for $\mathrm{C}_{21} \mathrm{H}_{24} \mathrm{NO}_{8}: 418.1502$. Found: 418.1505.

Computation Details Geometry optimization was performed with Spartan'18 ${ }^{37)}$ and the Gaussian 09 packages. ${ }^{38)}$
The ground-state geometries of all compounds were determined by means of the following successive steps: Conformational search with MMFF94, ${ }^{39)}$ then DFT calculation with B3LYP functionals. ${ }^{40)}$ The transition-state geometries of all compounds were determined by the DFT calculation with B3LYP functionals followed by IRC calculations. ${ }^{41,42)}$ The basis set employed for DFT geometry optimization was the native $6-31 G(d, p)$ for Fig. 1(a) or the native 6-31G(d) for Fig. 1(b)-(d).

Acknowledgments We thank Ms. Mizuki Yamazaki, Mr. Daichi Arai, and Ms. Akari Nakamura for assistance. This work was supported by JSPS KAKENHI Grant Number JP19K05473 and Kanazawa University SAKIGAKE project.

Conflict of Interest The authors declare no conflict of interest.

Supplementary Materials The online version of this article contains supplementary materials.

\begin{tabular}{|c|c|}
\hline Ref & ices \\
\hline 1) & Brieger G., Bennett J. N., Chem. Rev., 80, 63-97 (1980). \\
\hline 2) & Bear B. R., Sparks S. M., Shea K. J., Angew. Chem. Int. Ed., 40, \\
\hline & $820-849(2001)$ \\
\hline 3) & Ciganek E., Org. React., 32, 1-374 (1984). \\
\hline 4) & Fallis A. G., Can. J. Chem., 62, 183-234 (1984). \\
\hline 5) & Craig D., Chem. Soc. Rev., 16, 187-238 (1987). \\
\hline 6) & Takao K., Munakata R., Tadano K., Chem. Rev., 105, 4779-4807 \\
\hline & $(2005)$ \\
\hline 7) & Deagostino A., Maddaluno J., Prandi C., Venturello P., J. Org. \\
\hline & Chem., 61, 7597-7599 (1996). \\
\hline 8) & Takasu K., Mizutani S., Ihara M., J. Org. Chem., 67, 2881-2884 \\
\hline & $(2002)$ \\
\hline 9) & Corey E. J., Petrzilka M., Tetrahedron Lett., 16, 2537-2540 (1975). \\
\hline 10) & Bailey S. J., Thomas E. J., Turner W. B., Jarvis J. A. J., J. Chem. \\
\hline & Soc. Chem. Commun., 474-475 (1978). \\
\hline 11) & Greuter H., Schmid H., Fráter G., Helv. Chim. Acta, 60, 1701-1729 \\
\hline & (1977). \\
\hline 12) & Greuter H., Fráter G., Schmid H., Helv. Chim. Acta, 55, 526-531 \\
\hline & (1972). \\
\hline 13) & Greuter H., Schmid H., Helv. Chim. Acta, 55, 2382-2400 (1972). \\
\hline 14) & Liu X.-Y., Qin Y., Nat. Prod. Rep., 34, 1044-1050 (2017). \\
\hline & Hsu P.-Y., Peddinti R. K., Chittimalla S. K., Liao C.-C., J. Org. \\
\hline & Chem., 70, 9156-9167 (2005). \\
\hline 16) & Cook S. P., Danishefsky S. J., Org. Lett., 8, 5693-5695 (2006). \\
\hline & López C. S., Faza O. N., de Lera A. R., J. Org. Chem., 73, 467-473 \\
\hline & $(2008)$ \\
\hline 18) & Bhamare N. K., Granger T., John C. R., Yates P., Tetrahedron Lett., \\
\hline & 32, 4439-4442 (1991). \\
\hline 19) & Iwasawa N., Inaba K., Nakayama S., Aoki M., Angew. Chem. Int. \\
\hline & $E d ., \mathbf{4 4}, 7447-7450(2005)$. \\
\hline 0$)$ & For regioselectivity in construction of a bicyclo[2.2.2]octane skel- \\
\hline & eton by an IMDA reaction, see: Spangler J. E., Sorensen E. J., Tet- \\
\hline & rahedron, $\mathbf{6 5}, 6739-6745(2009)$ \\
\hline & Wessely I. F., Lauterbach-Keil G., Sinwel F., Monatsh. Chem., 81, \\
\hline & $811-818(1950)$ \\
\hline & Wessely F., Sinwel F., Monatsh. Chem., 81, 1055-1070 (1950). \\
\hline & Yates P., Auksi H., J. Chem. Soc. Chem. Commun., 1016-1017 \\
\hline & $(1976)$ \\
\hline & Yates P., Macas T. S., Can. J. Chem., 66, 1-10 (1988). \\
\hline & See supplementary materials. \\
\hline & Brossi A., J. Med. Chem., 33, 2311-2319 (1990). \\
\hline & Lin J., Zhang W., Jiang N., Niu Z., Bao K., Zhang L., Liu D., Pan \\
\hline
\end{tabular}


C., Yao X., J. Nat. Prod., 71, 1938-1941 (2008).

28) Lim L. H., Zhou J., Org. Chem. Front., 2, 775-777 (2015).

29) Schreiner P. R., Wittkopp A., Org. Lett., 4, 217-220 (2002).

30) Wittkopp A., Schreiner P. R., Chem. Eur. J., 9, 407-414 (2003).

31) Kim W. H., Lee J. H., Danishefsky S. J., J. Am. Chem. Soc., 131, 12576-12578 (2009).

32) Becke A. D., J. Chem. Phys., 98, 5648-5652 (1993).

33) Lee C., Yang W., Parr R. G., Phys. Rev. B Condens. Matter, 37, 785-789 (1988).

34) Han C., Fu Z., Guo S., Fang X., Lin A., Yao H., ACS Catalysis, 9, 4196-4202 (2019).
35) Huang C.-G., Wan P., J. Org. Chem., 56, 4846-4853 (1991).

36) Harayama T., Yasuda H., Heterocycles, 46, 61-64 (1997).

37) Shao Y., Molnar L. F., Jung Y., et al., Phys. Chem. Chem. Phys., 8, 3172-3191 (2006).

38) Gaussian 09, Revision A. 02, Frisch M. J., Trucks G. W., Schlegel H. B., et al. Gaussian, Inc., Wallingford, CT (2009).

39) Halgren T. A., J. Comput. Chem., 17, 490-519 (1996).

40) Becke A. D., J. Chem. Phys., 98, 5648-5652 (1993).

41) Gonzalez C., Schlegel H. B., J. Chem. Phys., 90, 2154-2161 (1989). 42) Gonzalez C., Schlegel B., J. Phys. Chem., 94, 5523-5527 (1990). 